\title{
Detection of $\alpha$-synuclein in biological samples using mass spectrometry
}

Ann Brinkmalm ${ }^{1}$, Annika Öhrfelt ${ }^{1}$, Payel Bhattacharjee ${ }^{1}$, Henrik Zetterberg ${ }^{1,2,3,4}$

1. Department of Psychiatry and Neurochemistry, Institute of Neuroscience and Physiology, the Sahlgrenska Academy at the University of Gothenburg, Mölndal, Sweden

2. Clinical Neurochemistry Laboratory, Sahlgrenska University Hospital, Mölndal, Sweden

3. Department of Molecular Neuroscience, UCL Institute of Neurology, Queen Square, London, $U K$

4. UK Dementia Research Institute at UCL, London, UK

*Correspondence: henrik.zetterberg@clinchem.gu.se; h.zetterberg@ucl.ac.uk

\begin{abstract}
Here we describe a method using mass spectrometry to characterize and quantify immuno-enriched a-synuclein forms from biochemically fractionated brain tissue.
\end{abstract}

\section{Key Words}

Parkinson's disease, $\alpha$-synuclein, mass spectrometry, CSF, brain

\section{Introduction}

The presynaptic neuronal protein $\alpha$-synuclein can misfold and form seeds that may aggregate further into intra-cellular inclusions that are called Lewy bodies. These inclusions are characteristic of Parkinson's disease (PD) and DLB (1), but are also frequently seen in AD (2). In PD and in other synucleinopathies, $\alpha$-synuclein concentrations in the CSF are typically lower than in healthy controls $(3,4)$, whilst in $\mathrm{AD}$ and CJD, its concentrations are increased and correlate with T-tau, indicating that $\alpha$-synuclein might also be a non-specific marker of neurodegeneration (4-8). 
Increased CSF levels of $\alpha$-synuclein have also been reported in DLB, where a competition might exist between the aggregation of $\alpha$-synuclein into Lewy bodies and its release from degenerating synapses, complicating the data interpretation (9). In agreement with this hypothesis, a recently published, multiple reaction monitoring mass spectrometry assay revealed significantly increased CSF concentrations of $\alpha-, \beta$ - and $\gamma$-synuclein in AD and CJD, but not in the 'classical' synucleinopathies like PD (10). Currently available assays for $\alpha$-synuclein measure the total amounts of the protein and not the Lewy body-specific isoforms. The availability of sensitive and specific assays for these pathogenic isoforms would resolve the issue of having the biomarker results influenced or confounded by the release of native $\alpha$-synuclein from degenerating synapses. However, there are some preliminary reports of increased concentrations of $\alpha$-synuclein oligomers in the CSF of PD patients $(11,12)$. Recent studies described sensitive assays that detect the amplified biochemical signal of $\alpha$-synuclein seeds that may be Lewy body-derived in the CSF from PD patients but not in healthy controls $(13,14)$, opening a promising avenue for using CSF $\alpha$ synuclein as a biomarker. Since $\alpha$-synuclein is highly expressed in red blood cells, blood contamination during CSF collection might limit its diagnostic value $(15,16)$. For the very same reason, blood tests for $\alpha$-synuclein pathology in the brain may lack the specificity needed for it to be an informative clinical biomarker. Nevertheless, as peripheral Lewy body pathology, such as in the salivary gland and the gut, has been reported in PD (17), blood or salivary tests for $\alpha$-synuclein seeds might be worth exploring in the future as a biomarker of PD and other dementias associated with Lewy bodies, such as DLB and AD. Altogether, additional fluid biomarkers are needed that are specific for pathological inclusions of $\alpha$-synuclein. To that end, we need methods to characterize $\alpha$-synuclein in biological samples. The method of choice to gain maximal information is mass spectrometry (MS). 
We here describe an MS-based method to characterize and quantify immuno-enriched $\alpha$-synuclein forms from biochemically fractionated brain tissue.

\section{Materials}

All solutions are prepared using ultrapure water (prepared by purifying deionized water, to attain a sensitivity of $18 \mathrm{M} \Omega$-cm at $+25^{\circ} \mathrm{C}$ ) and analytical grade reagents. Prepare and store all reagents at $+2-8{ }^{\circ} \mathrm{C}$ (unless indicated otherwise). Follow all waste disposal regulations when disposing waste materials.

\subsection{Tissue Sample Preparation Components}

1. Snap frozen blocks of brain tissue were stored at $-70{ }^{\circ} \mathrm{C}$ pending analyses. Working on dry ice the blocks are cut in approximately $100 \mathrm{mg}$ brain tissue. The tissues are transferred into pre-weighed polypropylene tubes and weighed. The tissue weight for each sample is then calculated.

2. Tris-buffered saline (TBS): $137 \mathrm{mM} \mathrm{NaCl}, 0.1 \mathrm{M}$ Tris- $\mathrm{HCl}, \mathrm{pH}$ 7.6. Weigh $1.6 \mathrm{~g} \mathrm{NaCl}$ and $485 \mathrm{mg}$ Tris base and transfer to a beaker. Add $150 \mathrm{~mL}$ water, mix and then adjust $\mathrm{pH}$ with $\mathrm{HCl}$. Transfer to a graduated cylinder and make up to $200 \mathrm{~mL}$ of water. Store at $+2-8{ }^{\circ} \mathrm{C}$.

3. TBS containing protease inhibitor: The protease inhibitor stock solution (x25) is prepared by solving 2 tablets of complete protease inhibitor (Roche, Ref no: 11697498001 ) in $4 \mathrm{~mL}$ water and can be used immediately or aliquoted and stored in $-20{ }^{\circ} \mathrm{C}$ for three months. Working solution is prepared immediately before use. Add 4 $\mathrm{mL}$ of the protease inhibitor stock solution (x25) to $96 \mathrm{~mL}$ of TBS.

4. $2 \%$ Triton X-100 containing protease inhibitor: Dissolve $1 \mathrm{~mL} 100 \%$ Triton X-100 in $49 \mathrm{~mL}$ TBS containing protease inhibitors with magnetic stirring at $+4^{\circ} \mathrm{C}$. The solution is prepared immediately before use. 
5. $90 \%$ formic acid (FA) aqueous solution: Inside a fume hood, add $45 \mathrm{~mL}$ of $100 \% \mathrm{FA}$ to a graduated cylinder and make up to $50 \mathrm{~mL}$ with water. Mix thoroughly and transfer to an air tight bottle. Keep at $+2-8{ }^{\circ} \mathrm{C}$ until further use.

6. Aqueous solution of $72.5 \mathrm{mM} \mathrm{NaCl}$ : Add $42.5 \mathrm{~g} \mathrm{NaCl}$ to $0.5 \mathrm{~L}$ water to prepare 1.45 $\mathrm{M} \mathrm{NaCl}$ stock solution, then the stock solution is further diluted $(1: 20 \mathrm{v} / \mathrm{v})$ with water to prepare working solution of $72.5 \mathrm{mM} \mathrm{NaCl}$ during brain tissue homogenate preparation.

7. $100 \mathrm{mM}$ Na-phosphate (pH 7.4): Weigh $2.68 \mathrm{~g} \mathrm{Na}_{2} \mathrm{HPO}_{4} \times 2 \mathrm{H}_{2} \mathrm{O}$ and $6.8 \mathrm{~g} \mathrm{NaH}_{2} \mathrm{PO}_{4}$ $\mathrm{x}_{2} \mathrm{O}$ and transfer to a beaker. Add $100 \mathrm{~mL}$ water and stir until dissolved. Adjust $\mathrm{pH}$ to 7.4. Transfer the solution to $250 \mathrm{~mL}$ graduated cylinder and adjust the volume to 200 $\mathrm{mL}$.

8. $0.3 \%$ n-octyl $\beta$-D-glucopyranoside (n-OGP) solution: Dissolve $0.6 \mathrm{~g} \mathrm{n}$-OGP in 200 $\mathrm{mL} 100 \mathrm{mM}$ Na-phosphate $(\mathrm{pH} 7.4)$, mix well on a roller at $+4{ }^{\circ} \mathrm{C}$ for $1-2 \mathrm{~h}$. The solution is stored at $+2-8{ }^{\circ} \mathrm{C}$ until further use.

9. Protein DC assay reagent (Bio-Rad Laboratories)

\subsection{Immunoprecipitation components}

1. Monoclonal anti- $\alpha$-synuclein Clone 42 antibody solution: Monoclonal anti- $\alpha-$ synuclein Clone 42 (BD Transduction Laboratories, Material number: 610787) (250 $\mathrm{mg} / \mathrm{L})$ are stored undiluted at $-20{ }^{\circ} \mathrm{C}$ pending analyses.

2. Magnetic beads: Magnetic Dynabeads ${ }^{\mathrm{TM}}$ Sheep anti-mouse IgG (Invitrogen)

3. Phosphate buffered saline (PBS) stock solution A: Add 42.5 g NaCl to 0.5L water 
4. PBS stock solution B: Weigh $6.7 \mathrm{~g} \mathrm{Na}_{2} \mathrm{HPO}_{4} \times 2 \mathrm{H}_{2} \mathrm{O}$ and $17 \mathrm{~g} \mathrm{NaH}_{2} \mathrm{PO}_{4} \times \mathrm{H}_{2} \mathrm{O}$ and transfer to a beaker. Add $450 \mathrm{~mL}$ water and stir until dissolved. Adjust $\mathrm{pH}$ to 7.4. Transfer the solution to $500 \mathrm{~mL}$ graduated cylinder and adjust the volume to $500 \mathrm{~mL}$.

5. PBS working solution: Mix $100 \mathrm{~mL}$ stock solution A with $100 \mathrm{~mL}$ stock solution B and $800 \mathrm{~mL}$ water in a glass bottle and store up to three weeks in $+2-8{ }^{\circ} \mathrm{C}$.

6. PBS containing 2.5\% Tween-20: To $1 \mathrm{~mL} \mathrm{10 \%} \mathrm{Tween-20} \mathrm{add} 3 \mathrm{~mL}$ PBS.

7. PBS containing 0.025\% Tween-20: Mix $1 \mathrm{~mL} \mathrm{2.5 \%} \mathrm{Tween-20} \mathrm{and} 99 \mathrm{~mL}$ PBS in a glass bottle and store up to three weeks at $+2-8^{\circ} \mathrm{C}$.

8. $20 \mathrm{mM}$ dimethyl pimelimidate dihydrochloride (DMP; Sigma-Aldrich) in $0.2 \mathrm{M}$ triethanolamine (TEA; Sigma-Aldrich): Dissolve 25 mg DMP (MW: $259.18 \mathrm{~g} / \mathrm{mol}$ ) in $5 \mathrm{~mL} 0.2 \mathrm{M}$ TEA (pH 8.2) and mix thoroughly. The solution is freshly prepared.

10. $50 \mathrm{mM}$ Tris- $\mathrm{HCl}(\mathrm{pH} 7.5)$ : Weigh $1.21 \mathrm{~g}$ Tris base and transfer to a beaker. Add 150 $\mathrm{mL}$ water, mix and then adjust $\mathrm{pH}$ with $\mathrm{HCl}$. Transfer to a graduated cylinder and make up to $200 \mathrm{~mL}$ of water. Store at $+2-8{ }^{\circ} \mathrm{C}$.

11. Roti-block solution: Dilute $1 \mathrm{~mL}$ Roti ${ }^{\circledR}-$ block (10x) (Carl Roth) with $9 \mathrm{~mL}$ water.

12. $50 \mathrm{mM}$ ammonium hydrogen carbonate $\left(\mathrm{NH}_{4} \mathrm{HCO}_{3}\right)(\mathrm{pH} \sim 8.0)$ : Weigh $0.395 \mathrm{~g}$ $\mathrm{NH}_{4} \mathrm{HCO}_{3}$ and transfer to a $100 \mathrm{~mL}$ graduated cylinder. Add $80 \mathrm{~mL}$ water, mix and make up to $100 \mathrm{~mL}$. Store at $+2-8^{\circ} \mathrm{C}$.

\subsection{On-bead digestion components}

1. $10 \mathrm{mM}$ dithiothreitol (DTT): Weigh $1.5 \mathrm{mg}$ DTT in a polypropelene tube, add $1 \mathrm{~mL}$ $50 \mathrm{mM} \mathrm{NH}_{4} \mathrm{HCO}_{3}$, and vortex.

2. $10 \mathrm{mM}$ iodoacetamide (IAM): Weigh $1.85 \mathrm{mg}$ IAM in a polypropelene tube, add 1 $\mathrm{mL} 50 \mathrm{mM} \mathrm{NH}_{4} \mathrm{HCO}_{3}$, and vortex. 
3. $0.01 \%$ hydrochloric acid aqueous $(0.01 \% \mathrm{HCl})$ solution: Inside a fume hood, add 27 $\mu \mathrm{L} 37 \% \mathrm{HCl}$ to a graduated cylinder and make up to $100 \mathrm{~mL}$ with water. Mix thoroughly and transfer to an air tight bottle. Keep at $+2-8{ }^{\circ} \mathrm{C}$ until further use.

4. Trypsin stock solution: Dissolve $20 \mu \mathrm{g}$ sequencing grade modified trypsin (Promega) in $200 \mu \mathrm{L} 0.01 \% \mathrm{HCl}$. Aliquot $10 \mu \mathrm{L}(0.1 \mathrm{~g} / \mathrm{L})$ stock solution and store in $-20{ }^{\circ} \mathrm{C}$ until use.

5. Trypsin solution: Thaw $10 \mu \mathrm{L}(0.1 \mathrm{~g} / \mathrm{L})$ trypsin stock solution, add $190 \mu \mathrm{L} 50 \mathrm{mM}$ $\mathrm{NH}_{4} \mathrm{HCO}_{3}$, and vortex.

6. $10 \%$ FA aqueous solution: Inside a fume hood, add $5 \mathrm{~mL}$ of $100 \%$ FA to a graduated cylinder and make up to $50 \mathrm{~mL}$ with water. Mix thoroughly and transfer to an air tight bottle. Keep at $+2-8{ }^{\circ} \mathrm{C}$ until further use.

\subsection{Stable Isotope-Labeled standards}

1. $15 \mathrm{~N} \alpha$-synuclein working solution $(10 \mathrm{fmol} / \mu \mathrm{L})$ : Dissolve $1 \mathrm{mg}$ recombinant $\alpha$ synuclein uniformly labeled with $15 \mathrm{~N}$-synuclein $(14,624 \mathrm{Da})$ in $1 \mathrm{~mL}$ water (resulting in $1 \mathrm{~g} / \mathrm{L}$ stock solution) and mix thoroughly. Prepare working solution by adding $14.6 \mu \mathrm{L}$ stock solution $(1 \mathrm{~g} / \mathrm{L}$ ) to $1 \mathrm{~mL}$ water (resulting in $1 \mathrm{pmol} / \mu \mathrm{L} 15 \mathrm{~N} \alpha$ synuclein solution). Dilute this solution 100 times in water to prepare the final working solution of $15 \mathrm{~N} \alpha$-synuclein $(10 \mathrm{fmol} / \mu \mathrm{L})$.

2. Stable isotope labeled standard peptides (SI peptides): $\alpha$-synuclein peptides were supplied by Thermo Fisher Scientific with at least one stable isotopically labeled amino acid. The purity of the peptides was $>95 \%$. Dissolve SI peptides in $1 \mathrm{~mL}$ water, aliquot and store stock solutions at $-70{ }^{\circ} \mathrm{C}$. Prepare SI peptide mix by adding each 
peptide stock solution to $50 \mathrm{mM} \mathrm{NH}_{4} \mathrm{HCO}_{3}$ and diluting to a concentration of 10 fmol $/ \mu \mathrm{L}$ per peptide.

\subsection{Consumables, Solutions, and Buffers for LC-MS/MS}

1. Loading buffer: Add $1 \mathrm{~mL} 100 \% \mathrm{FA}, 40 \mathrm{~mL}$ acetonitrile $(\mathrm{ACN})$ and $1960 \mathrm{~mL}$ water to a glass bottle, sonicate for $10 \mathrm{~min}$.

2. Buffer A: Add $1 \mathrm{~mL} \mathrm{100 \%} \mathrm{FA} \mathrm{and} 1 \mathrm{~L}$ water to a glass bottle, sonicate for $10 \mathrm{~min}$.

3. Buffer B: Add $840 \mathrm{~mL} \mathrm{ACN}, 160 \mathrm{~mL}$ water, and $1 \mathrm{~mL} \mathrm{100 \%} \mathrm{FA} \mathrm{to} \mathrm{a} \mathrm{glass} \mathrm{bottle,}$ sonicate for $10 \mathrm{~min}$.

4. $20 \% \mathrm{ACN}$ in aqueous $0.1 \%$ TFA: Add $20 \mathrm{~mL} \mathrm{ACN}, 10 \mathrm{~mL} 1 \%$ TFA and $70 \mathrm{~mL}$ water to a glass bottle. The solution can be stored at $+2-8^{\circ} \mathrm{C}$ for 1 month.

5. LC-vials: polypropylene LC vials

6. Nano LC-separation column: Acclaim PepMap RSLC C18, $2 \mu \mathrm{m}, 100 \AA$ А, $75 \mu \mathrm{m}$ i.d. x $15 \mathrm{~cm}$, nanoViper (Thermo Fisher Scientific)

7. Nano LC-trapping column: Acclaim PepMap 100 C18, length 500 mm; i.d. $75 \mu \mathrm{m}$, particle size $2 \mu \mathrm{m}$ ) (Thermo Fisher Scientific)

8. Micro LC-separation column: Hypersil Gold-C18 column (length $100 \mathrm{~mm}$, idiameter.d. $2.1 \mathrm{~mm}$, particle size $1.9 \mu \mathrm{m}$ ) (Thermo Fisher Scientific)

\section{Methods}

\subsection{Biochemical fractionation of brain tissue}

During the entire process below the samples should be kept on ice unless otherwise specified.

1. Thaw the samples of approximately $100 \mathrm{mg}$ brain tissue.

2. Homogenize the brain tissue in $1 \mathrm{~mL}$ ice cold TBS containing protease inhibitor.

3. Centrifuge the homogenate at $31,000 \mathrm{~g}$ for $1 \mathrm{~h}$ at $+4^{\circ} \mathrm{C}$.

4. Collect the supernatant (soluble fraction) and make aliquots to store at $-70^{\circ} \mathrm{C}$. 
5. Wash the pellet two times with TBS containing protease inhibitor. After each wash the samples are centrifuged at $31,000 \mathrm{~g}$ for $10 \mathrm{~min}$ at $+4^{\circ} \mathrm{C}$ and supernatants are discarded.

6. Add $0.8 \mathrm{~mL} 2 \%$ triton-X-100 containing protease inhibitor to the pellet.

7. Homogenize and sonicate for 30 seconds keeping the samples in an ice bath.

8. Centrifuge of the homogenate at $31,000 \mathrm{~g}$ for $1 \mathrm{~h}$ at $+4^{\circ} \mathrm{C}$.

9. Collect the supernatant (detergent soluble fraction) and make aliquots to store at $70^{\circ} \mathrm{C}$.

10. Wash the pellet two times with $2 \%$ triton-X-100 containing protease inhibitor. After each wash the samples are centrifuged at $31,000 \mathrm{~g}$ for $10 \mathrm{~min}$ at $+4^{\circ} \mathrm{C}$ and supernatants are discarded.

11. Add $0.8 \mathrm{~mL} 90 \% \mathrm{FA}$ to the pellet.

12. Homogenize and sonicate for 30 seconds keeping the samples in an ice bath.

13. Centrifuge of the homogenate at $31,000 \mathrm{~g}$ for $1 \mathrm{~h}$ at $+4{ }^{\circ} \mathrm{C}$.

14. Collect the supernatant (detergent insoluble fraction).

15. Dilute the detergent insoluble fraction immediately $(1: 20, \mathrm{v} / \mathrm{v})$ with aqueous $72.5 \mathrm{mM}$ $\mathrm{NaCl}$ in $50 \mathrm{~mL}$ conical tubes. Remove the cap of the tubes and wrap with parafilm. Make small pores on the parafilm layer and transfer the tubes to $-70{ }^{\circ} \mathrm{C}$ freezer immediately.

16. Lyophilize the frozen samples into complete dryness (see Note 1 and 2).

17. Reconstitute the dried sample in $0.5 \mathrm{~mL} 0.3 \% \mathrm{n}$-OGP solution in $100 \mathrm{mM} \mathrm{Na}$ phosphate (pH 7.4). Store at $-70{ }^{\circ} \mathrm{C}$.

18. The total protein concentration in each sample is determined by using Protein DC assay reagent according to the protocol from the manufacturer. 


\subsection{Immunoprecipitation}

The methodology described here is compatible with a KingFisher ${ }^{\circledR}$ magnetic particle processor (Thermo fisher scientific).

1. Vortex vial with magnetic beads carefully and transfer $50 \mu \mathrm{L}$ per sample to a new polypropylene vial.

2. Use a magnetic particle concentrator to pellet the beads for 3 min and wash with PBS (repeat three times).

3. Add $4 \mu \mathrm{L}$ of the mouse monoclonal anti- $\alpha$-synuclein antibody Clone $42(250 \mathrm{mg} / \mathrm{L})$.

4. Incubate $1 \mathrm{~h}$ on a rocking platform at room temperature $\left(\sim 20-25{ }^{\circ} \mathrm{C}\right)$.

5. Remove remaining unbound antibody by washing three times with PBS using the magnetic particle concentrator.

6. Cross-link the antibodies to the beads by resuspending the washed beads in $20 \mathrm{mM}$ DMP in $0.2 \mathrm{M}$ TEA.

7. Incubate $30 \mathrm{~min}$ on a rocking platform at room temperature.

8. Stop the reaction by placing the vial in the magnetic particle concentrator, removing the supernatant and resuspending in $50 \mathrm{mM}$ Tris- $\mathrm{HCl}$.

9. Incubate $15 \mathrm{~min}$ on a rocking platform at room temperature.

10. Wash the beads two times with PBS using the magnetic particle concentrator.

11. Resuspend in Roti-block solution.

12. Incubate $1 \mathrm{~h}$ on a rocking platform at room temperature.

13. Wash the beads two times with PBS using the magnetic particle concentrator and resuspend in PBS.

14. Add $25 \mu \mathrm{g}$ total protein (soluble and detergent soluble brain fractions) or $10 \mathrm{ug}$ total protein (detergent non-soluble brain fractions), $50 \mu \mathrm{L} 15 \mathrm{~N}$ labeled $\alpha$-synuclein, $10 \mu \mathrm{L}$ 
2.5\% Tween-20, $50 \mu \mathrm{L}$ antibody coupled magnetic beads, and PBS to a total volume of $1000 \mu \mathrm{L}$.

15. Incubate overnight on a rocking platform at $+4^{\circ} \mathrm{C}$.

16. Transfer incubated magnetic beads to the KingFisher® magnetic particle processor, tube 1 .

17. Conduct the following three wash steps (tubes 2-4) for $10 \mathrm{~s}$ in $1 \mathrm{~mL}$ of each washing buffer: (tube 2) $0.025 \%$ Tween-20 in PBS, (tube 3) PBS and (tube 4) $50 \mathrm{mM}$ $\mathrm{NH}_{4} \mathrm{HCO}_{3}, \mathrm{pH} \sim 8.0$.

18. Release the washed magnetic beads in $100 \mu \mathrm{L} 50 \mathrm{mM} \mathrm{NH}_{4} \mathrm{HCO}_{3}$ (tube 5).

19. Transfer the eluted fractions to $0.5 \mathrm{~mL}$ polypropylene tubes.

\subsection{On-bead digestion}

1. Reduce disulphate bridges by adding $10 \mu \mathrm{L} 10 \mathrm{mM}$ DTT to each sample, vortex and centrifuge for $10 \mathrm{~s}$ at $2000 \mathrm{~g}$.

2. Incubate for $30 \mathrm{~min}$ at $+60^{\circ} \mathrm{C}$ and cool down to room temperature for $15 \mathrm{~min}$.

3. Perform alkylation by adding $10 \mu \mathrm{L} 10 \mathrm{mM}$ IAM to each sample, vortex and centrifuge for $10 \mathrm{~s}$ at $2000 \mathrm{~g}$.

4. Incubate for $30 \mathrm{~min}$ at room temperature in dark.

5. Add $10 \mu \mathrm{L}$ trypsin solution and incubate in $+37^{\circ} \mathrm{C}$ overnight with shaking at $400 \mathrm{rpm}$.

6. Quench the reaction by adding $10 \mu \mathrm{L} 10 \% \mathrm{FA}$ aqueous solution.

7. Centrifuge at $16910 \mathrm{~g}$ for $10 \mathrm{~min}$ at $+4^{\circ} \mathrm{C}$.

8. Collect the supernatant in a $0.5 \mathrm{~mL}$ polypropylene tube and divide the supernatant into two tubes.

9. Speedvac to dryness.

\subsection{Data dependent nanoflow LC-MS/MS analysis and data base search}


The methodology described here is compatible with a Q Exactive ${ }^{\mathrm{TM}}$ Hybrid QuadrupoleOrbitrap $^{\mathrm{TM}}$ mass spectrometer coupled to a Dionex Ultimate 3000 RSLC nano system

1. Reconstitute one set of dried samples in $10 \mu \mathrm{L} 20 \% \mathrm{ACN}$ in aqueous $0.1 \%$ TFA (see Note 3).

2. Mix thoroughly for $1 \mathrm{~h}$, transfer $7 \mu \mathrm{L}$ of each samples to $\mathrm{LC}$ vials and place the vials in the autosampler of the LC system.

3. Program the LC to inject $5 \mu \mathrm{L}$ sample, and load the peptides on the trapping column with loading buffer at $5 \mu \mathrm{L} / \mathrm{min}$. After 2 minutes of washing the peptides are loaded on the separation column with $3 \%$ buffer B at $150 \mathrm{~nL} / \mathrm{min}$ and subsequently eluted with a $50 \mathrm{~min}$ linear gradient of $5 \%-40 \%$ buffer B.

4. Set the mass spectrometer to acquire positive ions in the data-dependent mode, with a scan cycle consisting of single microscans of one full scan mass spectrum followed by up to ten $\mathrm{MS}^{2}$ scans. Settings as follows: spray voltage $(+1.7 \mathrm{kV})$; capillary temperature $\left(+250^{\circ} \mathrm{C}\right)$; resolution $\left(70000 \mathrm{MS}, 17500 \mathrm{dd}-\mathrm{MS}^{2}\right)$; AGC target $(1 \mathrm{e} 6 \mathrm{MS}$, $5 \mathrm{e} 4 \mathrm{dd}-\mathrm{MS}^{2}$ ); maximum injection time (250ms MS, 60ms dd-MS ${ }^{2}$ ), m/z isolation window (m/z 300-1200 MS, m/z 2.0 dd-MS ${ }^{2}$ ). MS/MS scans are acquired with a normalized collision energy (NCE) setting of 28.0 for the ten most intense precursor ions with an intensity greater than $1.7 \mathrm{e} 4$, charge state $2-4$, and a dynamic exclusion for $50 \mathrm{sec}$.

5. Search acquired spectra with the following search parameters: database (Swissprot), taxonomy (Homo sapiens), enzyme (semi-trypsin), variable modifications (acetyl [Nterm] and oxidation $[\mathrm{M}]$ ), static modification (carbamidomethyl [C]), mass values (monoisotopic), peptide mass tolerance $( \pm 15 \mathrm{ppm})$, fragment mass tolerance $( \pm 20$ $\mathrm{mmu}$ ), and maximum 2 missed cleavages. 


\subsection{Assay development for Targeted microflow LC-MS/MS analysis}

The methodology described here is compatible with a Q Exactive ${ }^{\mathrm{TM}}$ Hybrid QuadrupoleOrbitrap $^{\mathrm{TM}}$ mass spectrometer coupled to a Dionex Ultimate 3000 system (Thermo Fisher Scientific).

1. Use nano LC-MS/MS data to select peptides to be quantified.

2. Let synthesize stable-isotope labelled (SI) peptides.

3. Dissolve SI peptides in LC-MS grade water, aliquot and store stock solutions at -70 ${ }^{\circ} \mathrm{C}$.

4. To 1 vial of stock solution add aqueous $20 \%$ ACN resulting in $1 \mu \mathrm{M}$ peptide concentration.

5. To select and optimize collision energy values maximizing fragment ion production infuse $1 \mu \mathrm{M}$ IS peptide solution into the mass spectrometer with a syringe at a flow rate of $5 \mu \mathrm{L} / \mathrm{min}$. After directly monitoring full mass scans and determining the most intense charge state set the mass spectrometer to acquire positive ions in the datadependent mode, with a scan cycle consisting of one full scan mass spectrum followed by one $\mathrm{MS}^{2}$ scan for 2 minutes. Settings as follows: spray voltage $(+1.7 \mathrm{kV})$; capillary temperature $\left(+250^{\circ} \mathrm{C}\right)$; resolution $(17500)$; AGC target (3e6 MS, 1e5 dd-MS $\left.{ }^{2}\right)$; maximum injection time (100ms), m/z isolation window (m/z 200-1800 MS, m/z 3.0 dd-MS ${ }^{2}$ ). MS/MS scans are acquired with an inclusion list of different normalized collision energies setting from 15 to 35 in random order

6. Thaw aliquots of the IS stock solutions, mix and dilute in $50 \mathrm{mM} \mathrm{NH}_{4} \mathrm{HCO}_{3}$ to a concentration of 
7. Thaw aliquots of the IS stock solutions, mix and dilute in $50 \mathrm{mM} \mathrm{NH}_{4} \mathrm{HCO}_{3}$ to a concentration of

8. Inject IS peptide mix several times and program the LC so to elute the peptides off the column using several different gradients

9. Optimize the LC gradient so that the retention times of the standard peptides are as far dispersed as possible

10. Select PRM transitions.

\subsection{Targeted microflow LC-MS/MS analysis}

1. Redissolve the second set of dried samples in $55 \mu \mathrm{L} \mathrm{SI} \mathrm{peptide} \mathrm{mix,} \mathrm{with} \mathrm{shaking} \mathrm{for}$ 1h. Transfer the samples to LC-vials and place the vials in the LC autosampler

2. Inject $50 \mu \mathrm{L}$ of each sample, which is loaded directly onto the analysis column with $0.1 \%$ aqueous $\mathrm{FA}$ at $300 \mu \mathrm{L} / \mathrm{min}$.

3. Program the LC so that after 2 min of loading, the peptides are eluted off the column using the following linear gradient steps: 0 min $0 \% \mathrm{~B} ; 4$ min $17 \% \mathrm{~B} ; 16 \mathrm{~min} 35 \% \mathrm{~B}$; $17.5 \min 100 \% \mathrm{~B} ; 20 \min 0 \% \mathrm{~B}$.

4. Set the mass spectrometer to acquire scheduled triplets of PRM scans at defined NCE allowing parallel detection of corresponding brain derived $\alpha$-synuclein peptide, IS peptides and the $15 \mathrm{~N}$ labeled peptide derived from the $15 \mathrm{~N}$ labeled recombinant $\alpha-$ synuclein. Mass spectrometry settings as follows:

5. Import acquired raw files into Pinpoint 1.3.0. Settings as follows: MS accuracy $( \pm 10$ ppm centered at 0$),$ MS/MS accuracy $( \pm 15 \mathrm{ppm})$, isolation mode (MS/MS with an isolation width of $3.0 \mathrm{u})$, chromatographic peak window size $( \pm 2.0 \mathrm{~min})$, peak area (four points of smoothing), scheduling window size $( \pm 0.5 \mathrm{~min})$. 
6. Inspect fragment ion peaks manually for accuracy of integration and absence of interferences from other peptides than the peptide of interest.

7. Calculate the relative amounts of the a-synuclein peptides $\mathrm{T}$ by taking the ratio between the sums of fragment ion peak areas of the brain derived peptides against the sum of fragment ion peak areas of the respective IS peptide. Since the purity of the IS peptides are not $100 \%$, normalizing with respect to the amount IS peptide present in the samples gives a rough estimate about the relative amount of the endogenous peptides of $\alpha$-synuclein in the brain tissue homogenates.

\section{Notes}

1. Evaporation of $\alpha$-synuclein to dryness by vacuum centrifugation should be avoided since a major part of the protein is not recovered after reconstitution.

2. A major challenge in studying the membrane-bound or LB associated proteins using mass spectrometry is the use of strong ionic and non-ionic detergents like SDS and triton X-100; chaotropic agents like urea, thiourea or guanidine and high concentration of organic acids like FA. These reagents are essential for solubilizing these types of proteins; however, they interfere with the IP, enzymatic digestion and mass spectral analysis by suppressing ionization and affecting chromatographic separation. In this study $2 \%$ triton-X-100 and $90 \%$ FA were used for solubilization of membrane-bound and LB enriched detergent insoluble fractions from brain respectively. The organic acid was removed by the process of lyophilization followed by reconstitution of the protein in presence of $0.3 \% \mathrm{n}-\mathrm{OGP}$ in $100 \mathrm{mM}$ phosphate buffer (pH 7.4).

3. Choice of reconstitution buffer will influence which forms (modifications and parts of sequence) of $\alpha$-synuclein that will be possible to detect with LC-MS.

\section{Acknowledgements}


6. Work in the authors' laboratories is supported by the Michael J. Fox Foundation (MJFF) for Parkinson's Research, the Swedish Research Council, the European Research Council, the Knut and Alice Wallenberg Foundation, the Torsten Söderberg Foundation, the Eivind and Elsa K:Son Sylvans Foundation, the Märtha and Gustaf Ågrens Foundation, the Olav Thon Foundation, Swedish State Support for Clinical Research (ALFGBG), Alzheimerfonden, Stiftelsen för Gamla Tjänarinnor, Frimurarestiftelsen

\section{References}

1. Mollenhauer B, El-Agnaf OM, Marcus K, Trenkwalder C, Schlossmacher MG. Quantification of alpha-synuclein in cerebrospinal fluid as a biomarker candidate: review of the literature and considerations for future studies. Biomark Med. 2010;4(5):683-99.

2. Schneider JA, Arvanitakis Z, Leurgans SE, Bennett DA. The neuropathology of probable Alzheimer disease and mild cognitive impairment. Ann Neurol. 2009;66(2):200-8.

3. Hall S, Ohrfelt A, Constantinescu R, Andreasson U, Surova Y, Bostrom F, et al. Accuracy of a panel of 5 cerebrospinal fluid biomarkers in the differential diagnosis of patients with dementia and/or parkinsonian disorders. Arch Neurol. 2012;69(11):1445-52.

4. Mollenhauer B, Locascio JJ, Schulz-Schaeffer W, Sixel-Doring F, Trenkwalder C, Schlossmacher MG. alpha-Synuclein and tau concentrations in cerebrospinal fluid of patients presenting with parkinsonism: a cohort study. Lancet Neurol. 2011;10(3):230-40.

5. Ohrfelt A, Grognet P, Andreasen N, Wallin A, Vanmechelen E, Blennow K, et al. Cerebrospinal fluid alpha-synuclein in neurodegenerative disorders-a marker of synapse loss? Neurosci Lett. 2009;450(3):332-5.

6. Slaets S, Vanmechelen E, Le Bastard N, Decraemer H, Vandijck M, Martin JJ, et al. Increased CSF alpha-synuclein levels in Alzheimer's disease: correlation with tau levels. Alzheimers Dement. 2014;10(5 Suppl):S290-8. 

fluid differentiates synucleinopathies (Parkinson Disease, dementia with Lewy bodies, multiple system atrophy) from Alzheimer disease. Alzheimer Dis Assoc Disord. 2012;26(3):213-6.

8. Wennstrom M, Surova Y, Hall S, Nilsson C, Minthon L, Bostrom F, et al. Low CSF levels of both alpha-synuclein and the alpha-synuclein cleaving enzyme neurosin in patients with synucleinopathy. PLoS One. 2013;8(1):e53250.

9. Kapaki E, Paraskevas GP, Emmanouilidou E, Vekrellis K. The diagnostic value of CSF alpha-synuclein in the differential diagnosis of dementia with Lewy bodies vs. normal subjects and patients with Alzheimer's disease. PLoS One. 2013;8(11):e81654.

10. Oeckl P, Metzger F, Nagl M, von Arnim CA, Halbgebauer S, Steinacker P, et al. Alpha-, Beta-, and Gamma-synuclein Quantification in Cerebrospinal Fluid by Multiple Reaction Monitoring Reveals Increased Concentrations in Alzheimer's and Creutzfeldt-Jakob Disease but No Alteration in Synucleinopathies. Mol Cell Proteomics. 2016;15(10):3126-38.

11. Hansson O, Hall S, Ohrfelt A, Zetterberg H, Blennow K, Minthon L, et al. Levels of cerebrospinal fluid alpha-synuclein oligomers are increased in Parkinson's disease with dementia and dementia with Lewy bodies compared to Alzheimer's disease. Alzheimers Res Ther. 2014;6(3):25.

12. Tokuda T, Qureshi MM, Ardah MT, Varghese S, Shehab SA, Kasai T, et al. Detection of elevated levels of alpha-synuclein oligomers in CSF from patients with Parkinson disease. Neurology. 2010;75(20):1766-72.

13. Fairfoul G, McGuire LI, Pal S, Ironside JW, Neumann J, Christie S, et al. Alpha-synuclein RT-QuIC in the CSF of patients with alpha-synucleinopathies. Ann Clin Transl Neurol. 2016;3(10):812-8. 14. Shahnawaz M, Tokuda T, Waragai M, Mendez N, Ishii R, Trenkwalder C, et al. Development of a Biochemical Diagnosis of Parkinson Disease by Detection of alpha-Synuclein Misfolded Aggregates in Cerebrospinal Fluid. JAMA Neurol. 2017;74(2):163-72.

15. Barbour R, Kling K, Anderson JP, Banducci K, Cole T, Diep L, et al. Red blood cells are the major source of alpha-synuclein in blood. Neurodegener Dis. 2008;5(2):55-9. 
16. Hong Z, Shi M, Chung KA, Quinn JF, Peskind ER, Galasko D, et al. DJ-1 and alphasynuclein in human cerebrospinal fluid as biomarkers of Parkinson's disease. Brain : a journal of neurology. 2010;133(Pt 3):713-26.

17. Uchihara T, Giasson BI. Propagation of alpha-synuclein pathology: hypotheses, discoveries, and yet unresolved questions from experimental and human brain studies. Acta Neuropathol. 2016;131(1):49-73. 